\title{
LATE PRECAMBRIAN PLASTIC DEFORMATION IN CRYSTALLINE LIMESTONE IN KUMLINGE, SOUTH-WEST FINLAND
}

\author{
Veli SuOMinen
}

\begin{abstract}
Suominen, Veli 1973: Late Precambrian plastic deformation in crystalline limestone in Kumlinge, South-West Finland. Bull. Geol. Soc. Finland 45, 49-52.

This paper is a preliminary description of a late Precambrian tectonization which plastically deformed a limestone and broke up a diabase occurring in the limestone. The diabase is Subjotnian in age. The offsetting of the diabase shows that there exists a tectonic deformation of relatively young age.
\end{abstract}

Veli Suominen, Geologisk mineralogiska institutionen, Abo Akademi, SF-20500 Abo 50, Finland.

The bedrock of Lilla Kvarnskär, a small island in the southern part of the parish of Kumlinge in the Alands Islands, SW Finland, consists of conformly striking leptite, crystalline limestone, and migmatite gneisses which presumably are metamorphosed supracrustal rocks. According to Sederholm, 1934, this supracrustal rock series belongs to the oldest parts of the Svecofennian orogenic belt, the Svionium. On Lilla Kvarnskär three diabase dikes of Subjotnian (late Precambrian) age cut these older rocks. The mobilization of limestone has faulted the smallest of the diabase dikes (see Fig. 1). On the southern shore of the island some narrow fissure filling sandstone dikes, probably Cambrian in age, cut the limestone.

Lilla Kvarnskär is located $85 \mathrm{~km} \mathrm{SW}$ of Turku (Åbo) and $50 \mathrm{~km}$ ENE of Mariehamn (map 1014 $12 \mathrm{~A})$. The coordinates of the outcrop (sketch and photos) are $\mathrm{x}=491.00, \mathrm{y}=6672.51 ; 60^{\circ}$ 9.8' N lat., $20^{\circ} 50.3^{\prime} \mathrm{E}$ long.

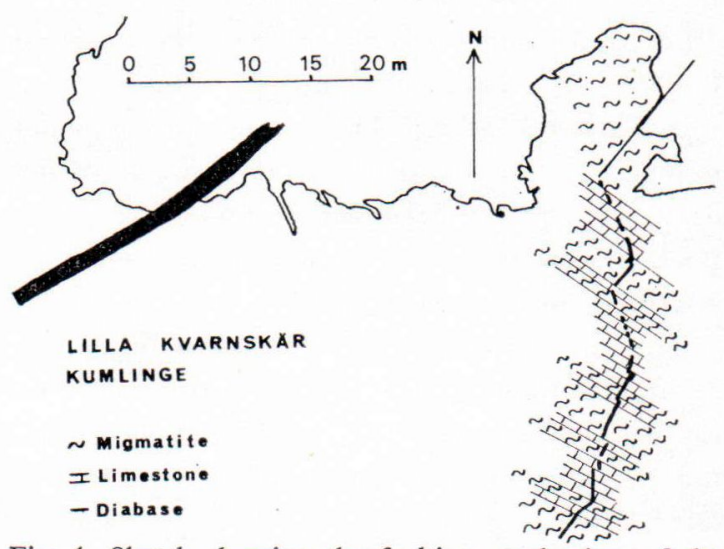

Fig. 1. Sketch showing the faulting mechanism of the movements in crystalline limestone.

The following relative age schema of the different rocks and events can be given:

Sandstone of Cambrian age

Tectonic deformation

Diabase of Subjotnian age

Folding and granitization

(oldest) Leptite, limestone 


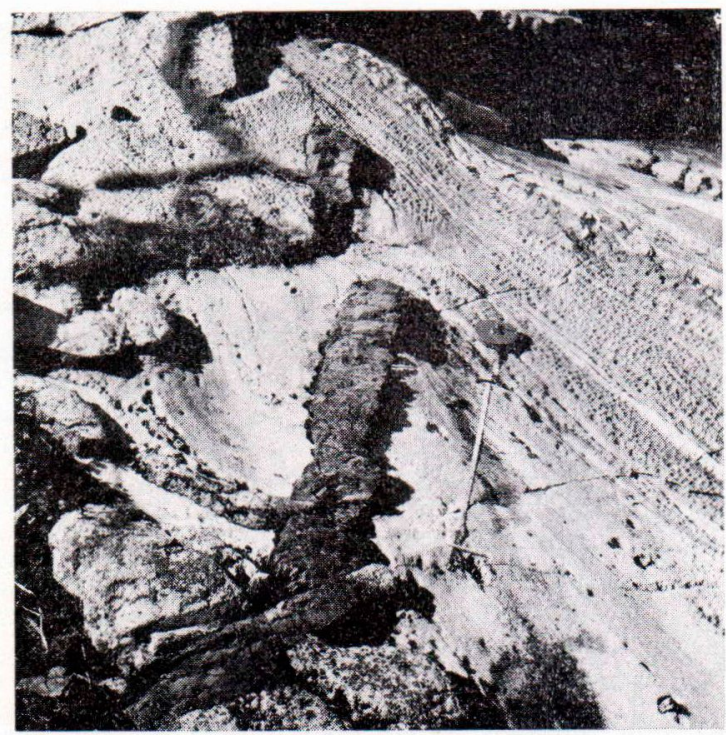

Fig. 2. The offset diabase dike cutting the limestone band with distinct foliation visible on the weathered surface.

Limestone occurs in leptite and migmatite gneisses as intercalations which are exposed on several places in fairly large outcrops. The structure of the limestone, which is similar to other ones in the leptite series in South-West Finland, is characterized by primary layering and tectonic banding. The latter is due to older movements that took place at a much earlier date than those now under discussion. Even in thick limestone bands, internal banding can be observed on weathered surfaces (see Fig. 2).

The limestone is composed of an almost pure calcite (containing $0.5-1.5 \% \mathrm{MgO}$ according to chemical analyses) together with dolomite, hornblende, chlorite, apatite, muscovite, plagioclase, olivine, garnet, quartz, diopside, epidote, titanite and biotite as accessory minerals.

Normally the limestone is coarse-grained and both it and its accessories are angular (see Fig. 3 A). Mobilized limestone is in places crushed and fine-grained. Larger diffuse-bordered grains of calcite are found only sporadically in the calcite matrix (see Fig. 3 B), in which the limestone is clearly foliated and the silicate minerals are rounded and highly orientated, elongated or flattened. The more coarse-grained calcite shows delicate twin lamellae. In the places in which the deformation is greatest calcite rhomohedrons are deformed.

Mica-poor leptite, competent during folding on Lilla Kvarnskär, occurs in the vicinity of limestone as is common in the archipelago zone in South-West Finland.

In the most migmatized places gneiss has completely changed into an irrecognizable pegmatitic migmatite granite that is very light-grey and poor in mica.

Some diopside skarn lenses containing traces of sulfides are to be found in the limestone.

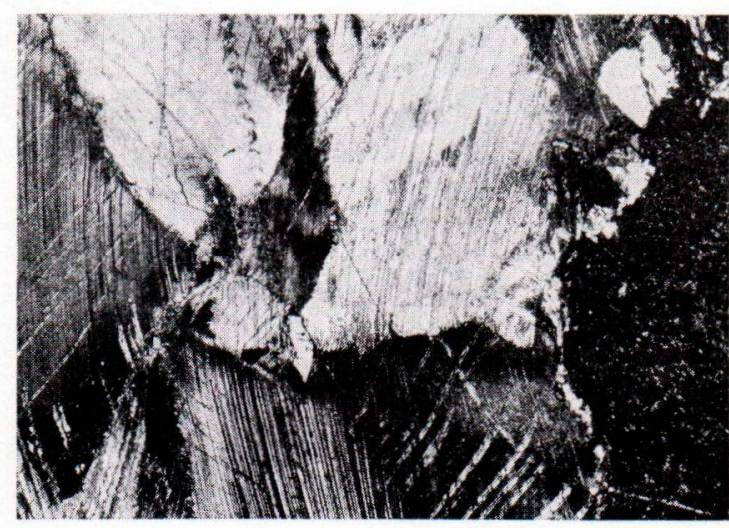

Fig. 3 A. Microphotograph of the contact between crystalline limestone and trapp diabase.

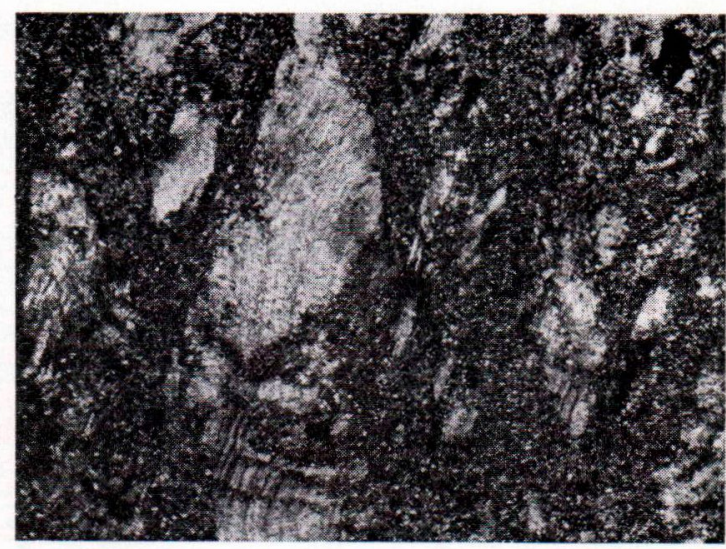

Fig. 3 B. Microphotograph of the crushed limestone. 
The diabase that cuts the leptites, limestone and gneisses is fine-grained and blackish green in color. It used to be called trapp diabase in geological literature. The trapp diabase is considered to be the youngest Precambrian rock in this region, and it is supposed to have intruded during the last orogenic movements.

The offset diabase dike is $25 \mathrm{~cm}$ wide and can be traced for approximately $30 \mathrm{~m}$ along the shore. It strikes N $40 \mathrm{E}$ with a vertical dip. The other two diabase dikes are about $1.5 \mathrm{~m}$ wide and their strike is the same as that of the offset diabase dike.

In the contact of the diabase with limestone a narrow more fine-grained zone can be noticed in diabase, although the difference between the diabase dike contact zone and inner part of the dike is not great. The limestone does not show any sign of internal reactions caused by the intrusion of diabase. In the contacts of diabase there are small tension cracks.

The rocks of the island show distinct folding. The largest folds are right hand folds. In places distinct marks of the mobilization and recrystallization of limestone are visible in the bedrock. Limestone was incompetent during folding, although the observed differences in competence are not distinct. Limestone bands remain conform without having squeezed into pressure minima. This holds true also in tightly folded places. In the most migmatized sites, limestone was squeezed into pressure minima as a completely plastic mass. In these cases the limestone is coarse-grained and obviously recrystallized.

In the middle of the island, at approximately $80 \mathrm{~m}$ from the offset diabase dike, there are some thin sandstone fissure fillings from 1 to $3 \mathrm{~cm}$ wide in the limestone. These dikes are similar to those described as Cambrian of age by Simonen and Kouvo (1955). They are emplaced in the limestone in the same direction as the diabase dikes but without any traces of later movements.

The fault that caused the plastic deformation is a wrench fault. It seems that the northern block of the island was moved NW in relation

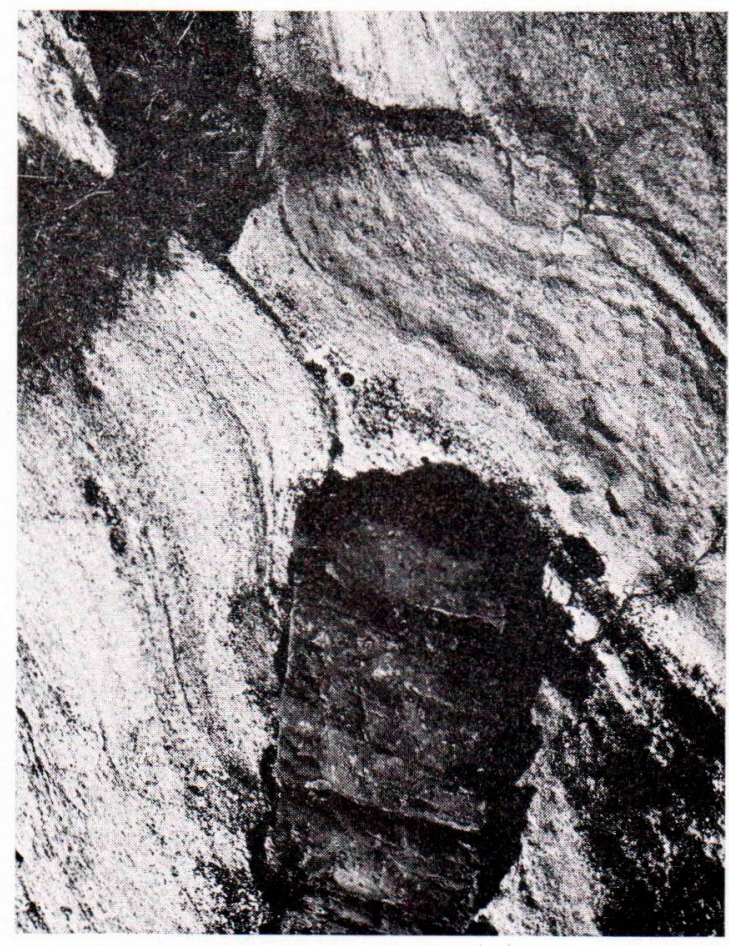

Fig. 4. The central area of Fig. 2. Limestone has been squeezed into the pressure minima.Diabase shows cleavage and the minor diabase fragment on the left is rounded.

to the southern block; the fault is left-handed. The horizontal movement measures about 17.5 m.

The movements took place in crystalline limestone, in which there are clear manifestations of recrystallization around the fragments of the diabase dike. Some fragments of the diabase exhibit distinct rounding of corners. There are clearly recognizable stream lines in the limestone and recrystallization is apparent in the pressure shadow (see Figs. 2 and 4).

Of the three diabase dikes only the narrowest is offset, which is due to the fact that in mobilization diabase acts as a brittle rigid wall. The thickest trapp diabase dikes are slightly curved. It is possible that the joints in which they intruded were originally of curved shape.

The diabase is offset without exception in the limestone bands, but is tectonically not effected in the leptite and migmatite gneisses. Within the 
limestone bands the diabase often shows a distinct fracture cleavage.

The deformation history of the bedrock of the island indicates that the sedimentation was followed by diagenese and folding. The folding was mainly non-cylindrical the axes having rotated in the axial plane.

Before the emplacement of the diabase the area was uplifted due to denudation. Since the rock was brittle tension joints which are now filled with diabase were formed. In subsequent movements limestone acted plastically at the same time as brittleness caused diabase to offset during faulting so that small tension cracks at the contacts and a distinct cleavage were formed. The fragments of diabase drifted from each other. During the brittle phase and contemporaneous with the emplacement of diabase limestone was nearer to the surface than during the plastic phase when the island was covered with sandstone, of which the dikes are a remnant. The present niveau of erosion is close to the Precambrian peneplain.

Evidently the movements were not very violent, because the rock was fairly cold at that stage. It is difficult to make any definite statements about the $\mathrm{P}-\mathrm{T}$ conditions as yet.

Limestone was mobile during the period between the intrusion of diabase and the beginning of the Cambrian age. The fact that the sandstone dikes have no offsets does not necessarily mean that the plastic deformation in limestone took place between Subjotnium and Cambrian, because the movements may have been concentrated on a narrow zone and might even be younger than Cambrian.

The leptite interlayers in limestone often have offsets containing signs of rotation (see Fig. 5).

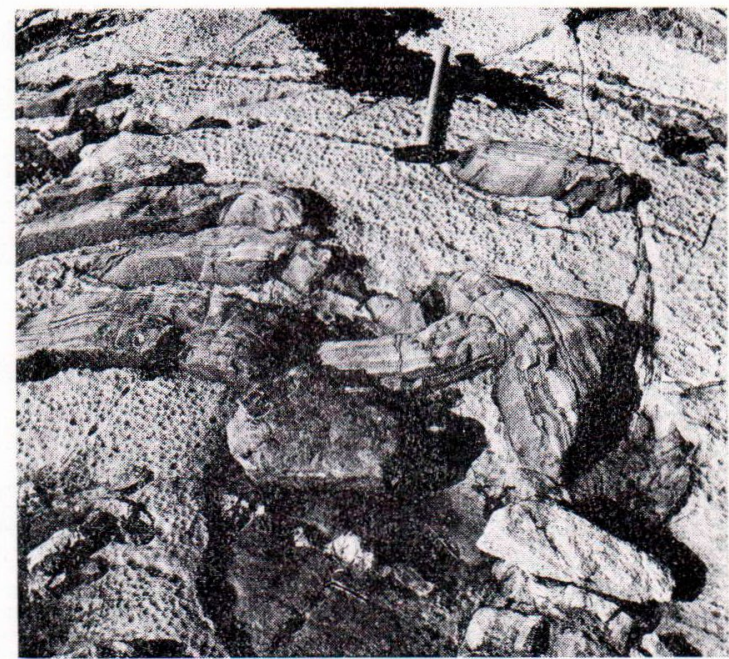

Fig. 5. Faulted leptite bands in limestone revealing pseudodiscordance due to rotation of the fragments.

This is a common feature of limestone in the whole region although offsets may also be associated with the folding phase.

The facts presented above suggest that plastic deformation took place in Precambrian rocks even after the intrusion of diabases which are regarded as the youngest Precambrian rocks in Finland. Similar movements possibly also occurred in migmatites and gneisses, although the evidence is not as easily obtainable as in the present case.

Acknowledgements - I wish to thank Professor Rudyard Frietsch, Mr. Gabor Gaál, Dr. phil., and Mr. Lennart Laurén, phil.lic., for critically reading the manuscript and for their help during the work. I wish to express my gratitude to Mrs. Eeva Honka and Mrs. Gillian Häkli for translating the manuscript. Suomen Luonnonvarain Tutkimussäätiö made the study possible with a grant. The chemical analyses were done by Paraisten Kalkki - Pargas Kalk Co.

\section{REFERENCES}

SEDERHolm, J. J. (1934) On migmatite and associated Precambrian rocks of Southwestern Finland, Part III: The Åland Islands. Bull. Comm. géol. Finlande 107.
Simonen, Ahti and Kouvo, Olavi (1955) Sandstones in Finland. Bull. Comm. géol. Finlande 168, pp. $57-87$.

Manuscript received, June 1, 1972. 